\title{
Ethical and Bioethical Aspects in the Use of Stem Cells in Chronic Spinal Cord Injuries
}

\author{
Alberto Benitez Herrera ${ }^{1}$, Pedro Rolando López Rodríguez ${ }^{2 *}$ \\ ${ }^{1}$ Professor Consultante, Profesor Titular, Especialista en Primero y Segundo Grado en Ortopedia y Traumatología. \\ ${ }^{2}$ Professor Consultante, Profesor Auxiliar, Especialista en Primero y Segundo Grado en Cirugía General e Investigador Auxiliar.
}

*Corresponding Author: Pedro Rolando López Rodríguez, Professor Consultante, Profesor Titular, Especialista en Primero y Segundo Grado en Ortopedia y Traumatología.

Received Date: September 30, 2021; Accepted Date: December 29, 2021; Published Date: January 03,2022

Citation: Alberto B Herrera, Pedro R L Rodríguez. (2022). Ethical and Bioethical Aspects in the Use of Stem Cells in Chronic Spinal Cord Injuries. International Journal of Clinical Case Reports and Reviews. 10(1); DOI:10.31579/2690-4861/179

Copyright: (C) 2022 Pedro Rolando López Rodríguez, This is an open-access article distributed under the terms of the Creative Commons Attribution License, which permits unrestricted use, distribution, and reproduction in any medium, provided the original author and source are credited.

\begin{abstract}
One of the fundamental dogmas maintained in neuroscience until the last century held that regeneration of the nervous system cannot occur in stages of adult life. However, it has been shown in several species during the postnatal stage and throughout life that new neurons continue to be generated in some places in the human body. Objectives: The research was: to evaluate ethical and bioethical aspects in patients who were treated with an autologous stem cell implant in chronic spinal cord injuries. Method. An analysis is made of the ethical aspects that accompany the implantation of autologous stem cells in chronic spinal cord injuries. The results are evaluated at the "Enrique Cabrera" Surgical Clinical Teaching Hospital. Results: Ethical dilemmas are expressed and that have, among their relevant principles, the inviolability of human life. In higher animals, stem cells according to their evolutionary state can be embryonic and somatic or adult. Currently there is an extraordinary controversy about which stem cells to use from embryonic or adult ones, a debate in which both scientific, ethical, religious, social and political aspects have been included. One aspect of the scientific debate is related to the generative capacity of tumors by embryonic cells. From the ethical point of view, it has been argued that the use of human embryonic stem cells implies the destruction of embryos and it has been considered that life begins at the same moment of the union of the sperm with the ovum and that this would be equivalent to the destruction of a human life which would not be justifiable. Others do not agree with these criteria and argue that their use to save lives through research or therapy would be justified.
\end{abstract}

Conclusions: The physical disability produced by a chronic spinal cord injury raises an ethical dilemma about the use of stem cells, anticipating that the main controversy about this action has to do fundamentally with the way in which they are obtained.

Keywords: stem cells; ethics; bioethics.

\section{Introduction}

Stem cell transplantation has recently become a promising therapeutic option for patients with lesions of the Central Nervous System (CNS). Many experimental studies have suggested that transplantation of stem cells from bone marrow, nerve progenitor cells, or cells from the olfactory mucosa could promote functional improvements after CNS injury [1-4]. In recent years, it has been shown that bone marrow-derived adult stem cells (MO-CMA) can differentiate into mature neurons or glial cells under specific experimental conditions [5-7]. These findings support the therapeutic potential of these cells in patients with neurological diseases and may obviate ethical problems given the possibility of treatment with autologous cells.
The CMA-MO graft has been actively studied in experimental models of spinal cord injury. The transplanted cells were able to improve the neurological deficit in the experimental models used by generating neural or myelin-producing cells [8-9]. The objectives being: Evaluate ethical and bioethical aspects in patients operated on for chronic spinal cord injury who underwent implantation of adult autologous stem cells.

\section{Methods}

An analysis is made of the ethical aspects that accompany the implantation of autologous stem cells in chronic spinal cord injuries, the results are evaluated. At the Enrique Cabrera General Teaching Hospital from October 2009 to October 2019. During this period 25 patients were operated on affected by this injury. 


\section{Results}

Ethical dilemmas are expressed and that have, among their relevant principles, the inviolability of human life. In higher animals, stem cells according to their evolutionary state can be embryonic and somatic or adult. Currently there is an extraordinary controversy about which stem cells to use from embryonic or adult ones, a debate in which both scientific, ethical, religious, social and political aspects have been included. One aspect of the scientific debate is related to the generative capacity of tumors by embryonic cells. From the ethical point of view, it has been argued that the use of human embryonic stem cells implies the destruction of embryos and it has been considered that life begins at the same moment of the union of the sperm with the ovum and that this would be equivalent to the destruction of a human life which would not be justifiable. Others do not agree with these criteria and argue that their use to save lives through research or therapy would be justified.

\section{Discussion}

Paraplegia and quadriplegia are sequelae of traumatic spinal injuries Espinal, in our investigation, generally produced by accidents of Transit or by immersion in shallow water. Most are patients relatively young with good prior health history than immediately after the accident they are left with a great physical disability that changes them abruptly their economic, social and emotional status, with a great loss in their quality of life, they are patients that are very difficult to treat and that entails careful attention by various medical specialties such as Neurosurgeons, Neurologists, Orthopedists, Rehabilitators and Psychologists. The term bioethics is a neologism first used by Potter in in 1973. It can be defined as the systematic study of human behavior in the area of human sciences and health care, insofar as this behavior is examined in the light of moral values and principles [10]. Bioethics encompasses a field greater than that of the strict doctor-patient relationship, it includes the problems related to values that arise in all health professions, with related professions and with mental health. It applies to biomedical research and behavior in applied therapeutics. It addresses a wide range of social issues, such as those related to public health, occupational health, and the ethics of birth control. It goes beyond human life and health, in that it encompasses issues relating to the life of animals and plants.

The modification of the name, from medical morals or ethics to bioethics, coincides with the beginning of a great development of this in the United States. There are two fundamental reasons that justify this change: on the one hand, the great development of the biomedical sciences, on the other, the fact that until the decade of the 1970s, the issues of medical morality were in the hands of theologians and thinkers of [11-12].

The interest that has focused on what some consider the "Revolution of Regenerative Medicine" is fundamentally based on new knowledge about the biology and potential of stem cells to become cells of different tissues. These discoveries have created great expectations about the application of cell therapy in different diseases, which has sometimes led to exaggerations that have overshadowed the reality regarding the use of stem cells. All this environment has unleashed a wide and often passionate ethical debate, in which sources of stem cells have been included as an outstanding topic, placing great emphasis on the obtaining and use of embryonic ones, and on the type of stem cell that could be the best therapeutic option. The main controversy revolves around embryonic stem cells and the use of human embryos. Regarding the sources of stem cells, it can be affirmed that the application of adult stem cells has been increasing and in particular of those from the bone marrow with which very encouraging results have been achieved. These cells can be extracted directly from the bone marrow, from the peripheral blood to which they have previously been mobilized through the use of growth-stimulating factors, such as granulocytic colony stimulating factor, and can also be collected from umbilical cord blood of the newborn. Promising results have also recently been achieved with stem cells from adipose tissue removed by liposuction [13]. In these cases, the ethical restrictions are those that are usually used in clinical trials and include the informed consent of the donor / recipient patient of the cells, which, because they are autologous, do not present the disadvantages of allogeneic ones. Consent for minors. The informed consent must be signed by the parents or guardians, and this consent must also be issued when the umbilical cord blood is drawn and signed by the mother of the newborn or by both parents as regulated. In all these situations, the possible benefits and risks of the procedure are explained to the signatories of the document, which must be well detailed in the text to be signed.

For clinical application, the protocol must be previously approved by the Ethics Committee of the institution where it will be carried out, so that the procedure is fully endorsed by ethical and scientific criteria and compliance with the ethical principles stipulated in the Declaration of Helsinki for research in humans.

Obtaining fetal cells involves the problems associated with the use of fetal tissues for research or treatment [14-15]. In this field, the use of spontaneously aborted fetuses and the use of those resulting from voluntary abortions are contemplated. Apparently there are no manifest contradictions about the use of human fetuses from a spontaneous abortion that has not been able to be avoided, but frequently they cannot be used because they have remained dead for several days before being aborted and generally their cells are no longer viable [14].

In the case of voluntary abortions, the opinion is that the necessary measures be taken to prevent abortions from being carried out for the purpose of providing material for research or therapeutic purposes. Thus, several situations have been related that, if there were at least one of them, would make the use of fetal tissue unacceptable. Among them we have the following: The mother did not grant the corresponding authorization. The request for the mother's consent is prior to the irrevocable decision to interrupt the pregnancy. The pregnant woman has some relationship with the possible beneficiary of the treatment. The woman will receive some compensation or benefit by giving consent. The abortion has been scheduled based on the subsequent use of fetal tissue. The possibility of the fetus being used as a donor has somehow prevented the woman from reversing her decision to abort. Opinions are divided here between those who do not object to the use of fetal material if the established restrictions are met and those who oppose its use anyway. It has been argued that approving voluntary abortion amounts to an authorization to deprive a human being of life, and that this is ethically unacceptable. As for stem cells from germ cell tumors, they have been used with success in some in vitro studies and in animal models without apparently raising ethical issues [13]. Given the increase in research with embryonic stem cells, surely the use of stem cells from teratomas an teratocarcinomas should decrease.

However, it should be noted that the most controversial ethical aspect is related to obtaining human embryonic cells, as this would mean ending the life of the embryos from which the cells are obtained [13]. These embryos can have different origins; more often they are embryos left over from in vitro fertilization as a procedure for assisted reproduction, but they could also be embryos obtained "in vitro" with the sole purpose of experimenting with them or. Well created by cloning, a process that corresponds to what has been called "therapeutic cloning" as opposed to the so-called "reproductive cloning" whose objective is to create an embryo to obtain a human being [14]. Obtaining embryos "in vitro" for the sole purpose of research has been judged by some as ethically unacceptable [15] and the issue of human cloning remains in great debate and with divided opinions among those who oppose any type of human cloning and those that accept only "therapeutic cloning" with rejection of "reproductive", the latter criterion that has been gaining progressively more support from the scientific community. The strongest argument used 
against obtaining human embryonic cells is that it produces the sacrifice of many embryos and for those who consider that life begins at the same moment of the union of the sperm with the ovum, this action would not be justifiable as it would amount to the destruction of human lives.

Against this criterion, it is pointed out that it is not clear that the life of an individual begins at the moment of fertilization, so it is debatable that individuality begins with fertilization. This has led some to believe that it is from the implantation of the embryo that there is human life and it is the period from which the embryo can be considered a human being. It has also been stated that low-quality embryos will never be selected for implantation and they agree with the use of the pre-embryo to save lives through research or therapy [16]. Recently, embryonic stem cells have been obtained that have been called "ethical stem cells", suggesting that this new method would eliminate the ethical dilemma of embryo destruction, since embryonic stem cells could be processed from a single blastomere that was extracted from a pre-embryo as early as that represented by a structure of 8 blastomeres without affecting the potential development of the embryo. [17-18]. However, strong criticisms were quickly made, reproaching the authors for exaggerating the results, since these were preliminary and the efficiency of the method was very low, since 91 cells were used out of 16 embryos and only 2 cell lines were created (around 2\%). In addition, it cannot be guaranteed that the biopsy for the extraction of the blastomere does not affect the embryo and it was also commented that this work is part of campaigns aimed at obtaining public funds for research and that it does not actually solve the ethical problem created by the use of embryos for regenerative therapy. [19-20] On the other hand, some researchers described the work as interesting but preliminary and others pointed out that it is possible that this method will solve current ethical concerns related to the destruction of human embryos. En oposición científicos de países en que es legal la producción de líneas de células madre embrionarias, a partir de embriones sobrantes obtenidos por los procedimientos de fertilización "in vitro", objetaron la idea de hacer investigaciones solo para evadir restricciones más bien políticas y señalaron que es más ético trabajar con embriones que de todas formas se van a destruir [21-25]. Por tanto las llamadas "células madre éticas" son aún un tema extraordinariamente polémico. La partenogénesis es otro método que también se ha propuesto para la obtención de células madre embrionarias y que puede contribuir a solucionar los problemas éticos actuales creados por la destrucción de embriones humanos [26]. Con esta técnica lo que se hace es activar el óvulo mediante estímulos químicos o físicos para obtener un embrión que se ha llamado embrión partenogénico. El producto de este proceder no es un verdadero embrión pues no llega a desarrollarse a término, razón por lo que se ha denominado "mola" o "huevo huero" [22]. De este producto artificial sería posible aislar células madre embrionarias que por provenir de una estructura que no es un verdadero embrión, no tendrían las implicaciones éticas que se argumentan con el uso de embriones. Otro punto para el análisis ético es el de la producción de líneas de células madre embrionarias humanas. En este sentido nadie acepta que se pague a quien dona los embriones para investigación, pero hay empresas que parecen estar dispuestas a registrar, patentar y comercializar esas líneas celulares. Este es un tópico sobre el cual surgirán, si no existen ya, muchas contradicciones desde el punto de vista ético, pues no es razonable que embriones donados para fines médicos se lleguen a convertir en productos biológicos comercializables que por otra parten por razones más bien financieras no llegarían a todos los que lo necesitan. Sobre qué tipo de célula madre, adulta o embrionaria, pudiera ser la mejor opción terapéutica, se ha analizado que una buena razón para priorizar por el momento la aplicación de las células madre adultas es que ya se conoce que ellas se han podido cultivar in vitro con un buen rendimiento, han evidenciado una versatilidad hasta hace poco insospechada y su aplicación terapéutica ha aportado resultados prometedores; aparte de que no presentan problemas éticos. Por supuesto esto no excluye continuar las investigaciones sobre las células madre embrionarias que a la luz de los conocimientos actuales están aún en fases preliminares. Además, las células de la médula ósea autóloga no están sometidas al sistema de propiedad intelectual pues pertenecen al propio paciente y se considera un deber médico demostrar si realmente son eficaces o no en la terapia celular regenerativa, pues al igual que se ha argumentado en relación con las cardiopatías, sería una verdadera pena si su eficacia no fuera ampliamente investigada y por esta razón se limitaran los beneficios que podrían recibir muchos enfermos [27]. Según han ido aumentando los conocimientos han ido también apareciendo muchas interrogantes, entre ellas algunas preocupaciones éticas, en gran parte aún sin respuesta pero que seguramente la tendrán en un futuro no lejano, de forma tal que se pueda definir el método más apropiado de terapia celular regenerativa y el verdadero sitio que ella debe ocupar en la práctica de la medicina actual en condiciones ética incuestionables. [28-29].

\section{Ethics and illness}

Regardless of their race, sex, political ideas, religion or socio-economic situation, guarantee equal opportunities and favor an equitable and efficient distribution of resources. You should try to get the best results with the least severe, they should undergo some type of diagnostic or treatment-oriented medical procedure. In intensive care units, opioids are used in patients with mechanical ventilation, the same ones that create dependence and some retrograde amnesia, however in terminal patients there should be no restrictions.

Chronic diseases require intensive and continuous treatment for many years or for life, and involve constant monitoring and adaptation of treatment to the course of the disease. Health professionals (doctors, clinical psychologists, nutritionists and nursing personnel) who carry out their care, teaching and research activities in the field of chronic diseases, have extensive experience on the difficulties involved in complying with medical regimens: it is time consuming, sometimes involves annoying or painful processes and can interfere with the daily routine, both for patients and their families. [25-26]. The character of our medicine constitutes the material base on which the morals and ethics of Cuban medicine workers are based, which engenders classist and partisan ethical principles radically opposed to bourgeois medical ethics. In the current circumstances in which the world lives, the underdeveloped countries continue to be the main victims, of the ethical dilemma of who should benefit mainly from new technological developments, those who can pay for it, or those who really need it. The doctor-patient relationship based and guided by humanism, must characterize our professionals with an ethic that reproduces in its demands the very profile of Cuban medicine [30].

\section{Conclusions}

The use of stem cells obtained from bone marrow of the same patient seems to have less ethical dilemma than the use of embryonic stem cells The physical disability produced by a chronic spinal cord injury poses an ethical dilemma that deserves to be well studied and known by all health personnel. The sense of beneficence, dignity and justice must make a difference and the high human sense of Cuban medicine.

\section{Conflicts of interest}

The authors do not declare any conflicts of interest.

\section{Authors' contributions}

Alberto Benitez Herrera: he reviewed the literature on the subject looking for epidemiological data worldwide, designed the study methodology, classified the research, processed the information and limited the bibliographic references according to Vancouver standards. He wrote the document.

Pedro Rolando López Rodríguez: he declared the study objectives, selected and triangulated the variables, and performed the English 
translation and final revision of the manuscript. He performed the statistical processing.

\section{References}

1. Ramer LM, Au E, Richter MW et al. (2004). Peripheral olfactory unsheathing cells reduce scar and cavity formation and promote regeneration after spinal cord injury. J Comp. Neurol. 473:1-15.

2. Pearse DD, Marcillo AE, Oudega M et al. (2004). Transplantation of Schwann cells and olfactory unsheathing glia after spinal cord injury: Does pre-treatment with methylprednisolone and interleukin-10 enhance recovery? J Neurotrauma. 21:1223-239.

3. Ogawa Y, Sawamoto K, Miyata T et al. (2002). Transplantation of in vitro-expanded fetal neural progenitor cells results in neurogénesis and functional recovery after spinal cord contusion injury in adult rats. J Neurosci Res. 69:925-933.

4. Koshizuka S, Okada S, Okawa a et al. (2004). Transplanted hematopoietic stem cells from bone marrow differentiate into neural lineage cells and promote functional recovery after spinal cord injury in mice. J Neuropathology Exp Neurol. 63:64-72.

5. Munoz-Elias G, Woodbury D, Black IB. (2003). Marrow stromal cells, mitosis, and neuronal differentiation: Stem cell and precursor functions. STEM CELLS. 21:437-448.

6. Sanchez-Ramos J, Song S, Cardozo-Pelaez F et al. (2000). Adult bone marrow stromal cells differentiate into neural cells in vitro. Exp Neurol. 164:247-256.

7. Ha Y, Yoon DH, Yeon DS et al. (2001). Neural antigen expressions in cultured human umbilical cord blood stem cells in vitro. J of Kor Neurosurg Soc. 30:963.

8. Chopp M, Zhang XH, Li Y et al. (2000). Spinal cord injury in rat: Treatment with bone marrow stromal cell transplantation. Neuroreport. 11:3001-3005.

9. Akiyama Y, Radtke C, Kocsis JD. (2002). Remyelination of the rat spinal cord by transplantation of identified bone marrow stromal cells. J Neurosci. 22:6623-6630.

10. Bellver V. (2006). Bioética de las células madre.

11. Sarría X. (2006). Ética de los trasplantes.

12. Nathanson B. (2006). Investigación y experimentación con tejido fetal.

13. Towns CR, Jones DG. (2004). Stem cells: public policy and ethics. NZ Bioeth. 5:22-28.

14. Schwartz PH, Rae 90SB. (2006). An approach to the ethical donation of human embryos for harvest of stem cells. Reprod Biomed online. 12:771-775.
15. Klimanskaya I, Chung Y, Becker S, LU J, Lanza R. (2006). Human embryonic stem cells lines derived from single blastomeres.

16. Marchant J. (2006). Human eggs supply "ethical” stem cells. Nature. 441:1038.

17. López-Moratalla N. (2006). La investigación con células madre embrionarias a 2005.

18. Abbott A. (2006). Ethical stem-cell paper under attack. Nature. 443:12.

19. Weissman IL. (2006). Medicine: Politic stem cells.

20. Lloren J. A. (2000). Ël juicio etico, un componente obligado en la atencion medica". Ateneo. 1(1):43-49.

21. Kawada H, Takizawa S, Takanashi T et al. (2006). Administration of hematopoietic cytokines in the subacute phase after cerebral infarction is effective for functional recovery facilitating proliferation of intrinsic neural stem/progenitor cells and transition of bone marrow-derived neuronal cells. Circulation. 113:701-710.

22. Chen Q, Long Y, Yuan X et al. (2005). Protective effects of bone marrow stromal cell transplantation in injured rodent brain: synthesis of neurotrophic factors. J Neurosci Res. 80:611-619.

23. Nehabat S, Selami A, Fatma G U. (2015). Chronic complications of spinal cord injury. World J Orthop. 6(1):2433.

24. World Health Organization. "Introducing the WHOQOL instruments“WHOQOL: Measuring Quality-of-.life Retrieved.

25. Park HC, Shim YS, Ha Y et al. (2005). Treatment of complete spinal cord injury patients by autologous bone marrow cell transplantation and administration of granulocyte-macrophage colony stimulating factor. Tissue Eng. 11:913-922.

26. Boakye M, Moore R, Kong M, Skirboill SL. \& Arrigo RT. (2013). Health related quality-of-life status in veterans with spinal disorders.

27. Seovane J. (1999). "Estilos y tipos de calidad de vida en el cuestionario de Sevilla“. Actas Esp. Psiquiatr. 27(4):245-249.

28. Bouhy D, Malgrange B, Multon S et al. (2006). Delayed GM$\mathrm{CSF}$ treatment stimulates axonal regeneration and functional recovery in paraplegic rats via an increased BDNF expression by endogenous macrophages. FASEB J. 20:1239-1241.

29. Lima C, Pratas-Vital J, Escada P et al. (2006). Olfactory mucosa autografts in human spinal cord injury: A pilot clinical study. J Spinal Cord Med. 29:191-203.

30. Dobkin BH, Curt A, Guest J. (2006). Cellular transplants in China: Observational study from the largest human experiment in chronic spinal cord injury. Neurorehabil Neural Repair. 20:56.
This work is licensed under Creative Commons Attribution 4.0 License
To Submit Your Article Click Here:

Submit Manuscrip
Ready to submit your research? Choose Auctores and benefit from:

$>$ fast, convenient online submission

$>$ rigorous peer review by experienced research in your field

$>$ rapid publication on acceptance

$>$ authors retain copyrights

$>$ unique DOI for all articles

$>$ immediate, unrestricted online access

At Auctores, research is always in progress.

Learn more https://auctoresonline.org/journals/international-journal-ofclinical-case-reports-and-reviews 